\title{
ANALISIS FAKTOR PENDORONG PERILAKU PEMBELI YANG MEMPENGARUHI KONSUMEN DALAM KEPUTUAN PEMBELIAN (Studi pada Swalayan di Kota Blitar)
}

\author{
Oleh : \\ Denok Wahyudi Setyo Rahayu \\ Universitas Islam Balitar \\ Email: denok.wahyudisr@gmail.com.
}

\begin{abstract}
The purpose of this research is to examine factor that influence purchasing behavior of customer in purchasing decision at Blitar city. the indicators is product, price, place, and promotion. Marketing mix with partial and simultaneous can be result different it. By using regression with F-test, hypothesis are proved significant. Research study at department store in Blitar city to show if purchasing decision will be because mix from product, price, place, and promotion. With combination all can be selling good. So, owner must do it if will many much profit.
\end{abstract}

Keywords: purchasing decision, product, price, place, promotion

\section{PENDAHULUAN}

Suatu kegiatan belanja tidak dapat terpisahkan dalam kehidupan seharihari. Hal ini menyangkut berbagai aspek. Adanya suatu kebutuhan dapat mendorong dalam suatu pembelian. Seperti halnya dengan kebiasaan membeli (buying habits) yang dilakukan oleh para konsumen. Buying habits (Alma, 2005 : 97) merupakan waktu kapan konsumen cenderung berbelanja. Hal tersebut dapat terjadi dalam kegiatan tertentu. Para pegawai pada umumnya berbelanja setelah menerima gaji di awal bulan. Pada kesempatan lain saat perayaan seperti hari raya toko-toko ramai dengan para pembeli yang berjubal. Hal tersebut dapat menjadi contoh dalam hal kebiasaan membeli para konsumen.

Dalam pembelian, selaku end user, konsumen dapat memilih jenis produk yang diinginkan sesuai selera konsumen. Oleh karena itu, produsen harus peka untuk hal tersebut. Pemberian rasa puas menjadi topik utama yang dilakukan produsen.Kepuasa konsumen dapat meanjadi tolok ukur loyalitas konsumen dalam konsmsi produk selanjutnya.

Terdapat 3 macam motif yang mempengaruhi seseorang untuk melakukan pembelian (Alma, 2005 : 97), yaitu : Primary buying motive, selective buying motive, dan patronage buying motive. Primary buying motive merupakan motif pembelian yang sebenarnya (contoh : orang lapar membeli nasi); selective buying motive yaitu pembelian barang yang berdasarkan rasio, waktu, maupun emosi (rational buying motive); patronage buying motive merupakan selective buying motive berdasarkan tempat (timbul karena layanan, lokasi dekat dan nyaman). 
Keputusan konsumen dalam melakukan pembelian dapat menjadi dasar bagi produsen untuk dapat mempertahankan atau bahkan meningkatkan kualitas produk yang dihasilkan. Hal tersebut dapat memberikan dampak positif bagi produsen dan juga penyalur produk termasuk agen, toko, distributor, karena dapat memberikan keuntunga. Pendistribusian produk yang tepat sasaran memberi dampak yang baik bagi konsumen sehingga produk tersebut dapat diminati oleh konsumen.

Pada penelitian, acuan penelitian dilakukan di swalayan yang ada di Kota Blitar. Upaya yang dilakukan adalah untuk mengetahui seberapa pengaruh dari faktor-faktor pendorong perilaku pembelian terhadap keputusan pembelian produk di swalayan Kota Blitar.

\section{Rumusan masalah}

Bagaimana faktor produk, harga, tempat, dan promosi berpengaruh secara simultan dan signifikan terhadap keputusan pembelian?

\section{Tujuan Penelitian}

Untuk mengetahui dan mendeskripsikan faktor produk, harga, tempat, dan promosi berpengaruh secara simultan dan signifikan terhadap keputusan pembelian.

\section{KAJIAN TEORI}

Keputusan pembelian (Kotler, 2002) merupakan tindakan dari konsumen untuk mau membeli atau tidak terhadap produk. Dalam kaitannya terdapat fungsi individu dalam melakukan keputusan pembelian (Kotler, et al, 1996), yaitu initiator, influencer, decider, buyer, dan user. Keputusan pembelian tersebut dapat dijabarkan sebagai berikut: (1) initiator merupakan individu yang memiliki ide dalam pembelian produk; (2) influencer, sebagai individu yang memberi pengaruh dalam pengambilan keputusan berdasarakan beberapa alternatif yang tersedia; (3) decider, merupakan individu yang memberikan keputusan terhadap produk mana yang akan dikonsumsi,; (4) buyer sendiri merupakan individu yang melakukan transaksi pembelian produk; (5) user merupakan pengguna produk tersebut. Kegiatan individu tersebut dapat terjadi oleh satu individu atau lebih.

Dalam melakukan pembelian terdapat hal-hal yang mendorong konsumen untuk membeli, seperti halnya gambar 1 di bawah ini : 


\section{Gambar 1 \\ Model of Buyer Behavior}

Marketing and

Buyer's black box

Buyer's responses

other stimuli

\begin{tabular}{|l|l|}
\hline $\begin{array}{l}\text { Product } \\
\text { Price } \\
\text { Place } \\
\text { Promotion }\end{array}$ & $\begin{array}{l}\text { Economic } \\
\text { Technological } \\
\text { Political } \\
\text { Cultural }\end{array}$
\end{tabular}$\longrightarrow$\begin{tabular}{|l|l|}
$\begin{array}{l}\text { Buyer } \\
\text { characteri } \\
\text { stics }\end{array}$ & $\begin{array}{l}\text { Buying } \\
\text { decision } \\
\text { process }\end{array}$ \\
\hline
\end{tabular}

Product choice

Brand choice

Dealer choice

Purchase timing

Purchase

amount

Sumber dimodifikasi (Kotler \& Amstrong, 1999:135)

Berdasarkan Gambar 1 dapat dijelaskan bahwa terdapat suatu dorongan yang bersal dari jenis produk, harga, tempat, serta promosi. Selain itu juga didorong oleh faktor-faktor seperti ekonomi (keuangan konsumen), teknologi, politik, serta budaya yang merupakan suatu informasi penting bagi konsumen. Faktor-faktor tersebut masuk ke dalam black box konsumen menjadi suatu informasi kemudian diolah oleh konsumen dan akhirnya didapatkan hasil kesimpulan dari informasi tersebut berupa tanggapan yang muncul mengenai produk apa yang akan dibeli, merek produk, pemilihan toko, waktu pembelian, serta banyaknya produk yang akan dibeli oleh konsumen.

Faktor-faktor dalam perilaku pemberian diantaranya adalah, produk, harga, tempat, dan promosi (gambar 1, pendorong dalam pembelian). Produk merupakan seperangkat atribut baik berwujud maupun tidak berwujud, termasuk didalamnya warna, harga, nama baik pabrik, nama baik toko yang menjual (pengecer), dan pelayanan pabrik serta pelayanan pengecer, yang diterima oleh pembeli guna memuaskan keinginannya (Stanton, 1981:192), sedangkan Kotler (2000:394) mengartikan produk sebagai segala sesuatu yang dapat ditawarkan di pasar, untuk memuaskan kebutuhan dan keinginan konsumen, yang terdiri atas barang, jasa, pengalaman, event, orang, tempat, kepemilikan, organisasi, informasi, dan ide. Sehingga produk merupakan sesuatu yang ditawarkan oleh penjual baik berwujud maupun tidak berwujud dalam rangka memenuhi kebutuhan konsumen. Sehingga produk dapat diartikan sebagai sesuatu dengan segala hal yang melekat yang bertujuan untuk memuaskan kebutuhan konsumen. Terdapat 3 klasifikasi produk (Tjiptono, 1997:98), yaitu : (1) berdasarkan wujudnya (barang dan jasa). Barang yang dimaksud adalah sesuatu yang dapat disentuh, diraba, dipegang, dsb, sedangkan jasa merupakan aktifitas atau manfaat yang ditawarkan untuk dikonsumsi oleh konsumen; (2) berdasarkan barang konsumen : convinience goods (memiliki frekuensi tinggi dalam pembelian, dibutuhkan dengan sesegera mungkin dengan usaha yang minimum, contoh : sabun, surat kabar), shopping goods (konsumen dalam membeli masih membandingkan dengan alternatif yang lain yang tersedia, contoh : 
pakaian,sepatu,dll), specialty goods (barang-barang yang memiliki karakteristik tertentu sehingga konsumen bersedia melakukan usaha untuk mendapatkan barang-barang tersebut, contoh : mobil mewah, pakaian rancangan disainer terkenal), unsought goods (barang-barang yang sudah ataupun belum diketahui konsumen dan konsumen masih belum ingin membelinya, contoh : ensiklopedia, asuransi jiwa); (3) barang industri : Materials and parts (barang-barang yang sepenuhnya masuk daam produk jadi, contoh : benang, semen), capital items (barang-barang tahan lama yang memberi kemudahan dalam mengembangkan produk jadi, contoh : mesin bor, mesin diesel), supplies and services (barangbarang tidak tahan lama dan jasa yang memberi kemudahan dalam mengembnagkan/mengelola keseluruhan produk jadi, contoh : supplies, cat, minyak pelumas; services, konsultasi manajemen).

Selanjutnya terdapat kesepakatan antara penjual dan pembeli juga menjadi pendorong seseorang dalam melakukan pembelian. Kesepakatan ini disebut dengan harga. Atau dengan kata lain harga bisa diartikan sebagai nilai suatu barang yang dinyatakan dengan uang (Alma, 2005:169). Harga merupakan jumlah uang (ditambah beberapa produk, kalau mungkin) yang dibutuhkan untuk mendapatkan sejumlah kombinasi dari produk dan pelayanan (Swastha, 1999:241). Dalam harga biasanya dibelakukan suatu kebijakan harga, hal ini dilakukan untuk menghindari persaingan dan juga untuk memasuki pasar-pasar baru. Kebijaksanaan harga ang biasa dilakukan retailer untuk mengenakan hati konsumen antara lain dapat dipaparkan sebagai berikut (Alma, 2005:173): (1) margin pricing, penentuan harga yang berdasarkan biaya-biaya yang dikeluarkan untuk memproduksi produk tsb; (2) price lining, penggolongan barang-barang, untuk memudahkan pemilihan barang bagi konsumen yang dananya terbatas, contoh : penggolangan barang dengan bandrol harga Rp. 35.000,00 , Rp. $50.000,00$, sehingga bagi konsumen yang dananya terbatas dapat membeli barang yang lebih murah; (3) competitors price, penetapan harga murah bagi barangbarang yang dikenal oleh umum; (4) discount house, potongan harga bagi barangbarang yang dijual; (5) judgement pricing, harga barang berdasarka perkiraan penjual yang didasarkan pada keunukan barang; (6) customary price, kestabilan harga barang dalam jangka panjang; (7) odd price, menurunkan harga dengan nilai, contoh : barang yang seharusnya Rp. 5.000,00 dibandrol menjadi Rp. 4.800,00 sehingga secara psikologis konsumen akan merasa diuntungkan bila membeli barang tersebut karena lebih murah; (8) combinations offers, mengkombinasi barang yang dijual, conto : shampo dengan sabun.

Selain itu tempat menjadi salah satu faktor dalam perilaku embelian. Tempat diartikan sebagai dimana barang tersebut dijual. Berbagai macam lingkungan dapat digunakan sebagai tempat untuk memajang barang. Pertokoan bahkan dipinggir jalan. Tempat sangat berpengaruh bagi konsumen dalam memutuskan untuk melakukan pembelian. Pada swalayan konsumen menganggap barang yang dijual lebih prestisius apalagi bila didukung dengan suasana swalayan yang menunjang. Tempat disini dapat pula diartikan sebagai sarana distribusi atau perantara, yaitu orang atau perusahaan yang menghubungkan aliran barang drai produsen ke konsumen akhir dan konsumen industrial (Stanton, et al., dalam Tjiptono,1997 :185). Dengan adanya perantara maka konsumen akan lebih 
mudah untuk memperoleh barang yang dinginkan. Banyak hal yang harus diperhatikan dalam hal ini, karena seorang distributor harus kreatif dalam menyajikan produk yang ditawarkan sehinga dapat menarik konsumen untuk mengkonsumsi produk tersebut. Contohnya, sebual swalayan dalam display kue kering harus bisa terlihat menarik sehingga konsumen tertarik untuk membelinya. Ini adalah salah satu cara yang dapat dilakukan oleh swalayan.

Promosi menjadi acuan selanjutnya. Shoell (Alma, 2005:179) menyatakan promotion is marketers' effort to communicate with target audience. Communication is the process of influencing others' behavior by sharing ideas, information or feeling with them. Promosi harus dilakukan oleh produsen atau penjual agar barang yang dihasilka atau dijual dapat laku di pasaran. Berbagai cara dapat dilakukan dalam mempromosikan suatu barang, antara lain (Alma, 2005: 189): (1) display (menonjolkan tampilan yang bisa dipajang di etalase toko, melaui tampilan interior maupun eksterior), tujuannya untuk memperkenalkan produk secara cepat dan ekonomis dalam hal ini juga menguntungkan produsen, sebagai advertising dan mecchandising, serta membina hubungan baik dengan konsumen; (2) show, pertunjukan misal fashion show; (3) exposition, seperti promosi tingkat internasional; (4) demonstration, peragaan produk, misal peragaan sabun pencuci piring; (5) tradding stamps, cap dagang, misal bila konsmen memiliki jumlah cap tertentu maka akan mendapatkan potongan harga; (6) packaging, tampilan kemasan barang; (7) labelling, keterangan ciri barang; (8) special sales, memberi potongan harga.

Selain itu, beberapa peneliti tidak membedakan antara pemahaman konsep pembelian impulsif (impulsive buying) dan pembelian tidak direncanakan (unplanned buying). Philipps dan Bradshow (1993), dalam Bayley dan Nancarrow (1998) tidak membedakan antara unplanned buying dengan impulsive buying, tetapi mereka memberikan perhatian penting kepada peneliti bahwa harus mengfokuskan pada interaksi antara point-of-sale dengan pembeli yang sering diabaikan. Unplanned buying adalah suatu tindakan pembelian yang dibuat tanpa direncanakan sebelumnya atau keputusan pembelian dilakukan pada saat berada didalam toko (Engel dan Blacwell, 1982). Selanjutnya, Cobb dan Hayer (1986) mengklasifikasikan suatu pembelian impulsif terjadi apabila tidak terdapat tujuan pembelian merek tertentu atau kategori produk tertentu pada saat masuk kedalam toko.

\section{HIPOTESIS}

Faktor produk, harga, tempat, dan promosi secara simultan dan signifikan berpengaruh terhadap keputusan pembelian?

\section{METODOLOGI PENELITIAN Variabel Penelitian}

Variabel bebas

: Faktor pendorong perilaku pembelian sebagai $\mathrm{X}$ (indikator : produk, harga, tempat, dan promosi).

Variabel terikat $\quad$ keputusan pembelian (Y) 


\section{Populasi dan Sampel Penelitian}

Populasi dalam penelitian ini adalah konsumen yang melakukan pembelian di beberapa swalayan di Kota Blitar dengan sampel sebanyak 100 responden (jumlah pernyataan ada 10 pertanyaan, yakni pada variabel produk 2 indikator, harga 2 indikator, tempat 3 indikator, promosi 2 indikator, dan keputusan pembelian 1 indikator, sehingga $10 \times 10=100$ responden; sesuai dengan pernyataan Roscoe dalam Sugiyono,2007:74). Teknik pengambilan sampel menggunakan teknik acidental sampling,yaitu siapa saja yang ditemui dapat digunakan sebagai sampel (pembeli pakaian).

Sesuai dengan model perilaku pembelian (Kotler \& Amstrong), penelitian ini akan memfokuskan pada produk $\left(\mathrm{X}_{1}\right)$, harga $\left(\mathrm{X}_{2}\right)$, tempat $\left(\mathrm{X}_{3}\right)$, dan promosi $\left(\mathrm{X}_{4}\right)$ sebagai variabel bebas yang mengarahkan pada keputusan pembelian bagi konsumen terhadap suatu produk sebagai variabel terikat dimana keputusan pembelian (Y) dilakukan berdasarkan buying habbits dari konsumen tersebut.

\section{Waktu dan Tempat}

Penelitian dilakukan pada bulan Februari 2018 selama 1 bulan dengan lokasi di beberapa swalayan Kota Blitar.

\section{Definisi Konseptual dan Operasional}

\section{a. Definisi konseptual}

a) Keputusan pembelian (Kotler, 2002) merupakan tindakan dari konsumen untuk mau membeli atau tidak terhadap produk.

b) Produk sebagai segala sesuatu yang dapat ditawarkan di pasar, untuk memuaskan kebutuhan dan keinginan konsumen, yang terdiri atas barang, jasa, pengalaman, event, orang, tempat, kepemilikan, organisasi, informasi, dan ide (Kotler, 2000:394).

c) Harga adalah jumlah uang (ditambah beberapa produk, kalau mungkin) yang dibutuhkan untuk mendapatkan sejumlah kombinasi dari produk dan pelayanan (Swastha, 1999:241).

d) Tempat (distributor) adalah orang atau perusahaan yang menghubungkan aliran barang drai produsen ke konsumen akhir dan konsumen industrial (Stanton, et al., dalam Tjiptono,1997:185).

e) Promosi menyatakan promotion is marketers' effort to communicate with target audience. Communication is the process of influencing others' behavior by sharing ideas, information or feeling with them (Shoell dalam Alma, 2005:179).

\section{b. Definisi operasional}

a) Keputusan pembelian merupakan suatu tindakan yang dilakukan konsumen antara membeli atau tidak membeli produk yang tersedia.

b) Produk merupakan sesuatu yang ditawarkan oleh penjual baik berwujud maupun tidak berwujud dalam rangka memenuhi kebutuhan konsumen.

c) Harga merupakan nilai tukar dari suatu barang yang dinyatakan dengan satuan nilai uang. 
d) Tempat merupakan swalayan tempat produk dipasarkan.

e) Promosi merupakan suatu media dalam rangka mempengaruhi pembeli untuk membeli produk yang ditawarkan.

Pengukuran dilakukan dengan menggunakan skala likert dengan ketentuan sangat setuju (5), setuju (4), netral (3), kurang setuju (2), dan sangat tidak setuju (1). Sedangkan analisis data menggunakan regresi linier berganda dengan menggunakan program SPSS.

\section{HASIL DAN PEMBAHASAN}

Berdasarkan hasil pengolahan data, hasil uji validitas dari kuisioner variabel produk $\left(\mathrm{X}_{1}\right)$, harga $\left(\mathrm{X}_{2}\right)$, tempat $\left(\mathrm{X}_{3}\right)$, promosi $\left(\mathrm{X}_{4}\right)$, serta keputusan pembelian (Y) menunjukkan semua variabel memiliki r-hitung lebih besar dari rtabel sehingga dinyatakan valid. Sedangkan untuk uji reliabilitas berdasarkan kuisioner menunjukkan semua variabel memiliki r-aplha lebih besar dari r-tabel sehingga kuisioner yang disusun dinyatakan reliabel.

Uji hipotesis menunjukkan jika $\left(0,05 \leq\right.$ sig) berarti $\mathrm{H}_{0}$ diterima dan $\mathrm{H}_{\mathrm{a}}$ ditolak artinya tidak signifikan, sedang jika $(0,05 \geq \operatorname{sig})$ berarti $\mathrm{H}_{0}$ ditolak dan $\mathrm{H}_{\mathrm{a}}$ diterima artinya signifikan. Dalam penelitian pada uji hipotesis diperoleh hasil sbb : hipotesis $(0,05 \geq 0,006)$ sehingga hipotesis dinyatakan signifikan.

Produk, harga, dan tempat secara parsial ternyata tidak berpengaruh signifikan terhadap keputusan pembelian, sedangkan promosi secara parsial berpengaruh signifikan terhadap keputusan pembelian. Jika dilihat secara simultan, produk, harga, tempat, dan promosi berpengaruh secara signifikan terhadap pembelian impulsif.

Dari uji hipotesis tersebut, dapat dinyatakan bahwa untuk melakukan keputusan pembelian terhadap produk-produk yang ada di swalayan Kota Blitar oleh para konsumen, maka penjual atau pemilik swalayan hendaknya melakukan penawaran yang terbaik, yaitu penawaran dari produk yang dijualdengan harga yang menggiurkan, tempat atau lokasi yang mendukung seperti suasana toko, lahan parkir yang luas, serta promosi yang menarik. Hal ini sesuai dengan penelitian yang telah dilakukan, dengan berdiri sendiri maka variabel-variabel tersebut tidak bisa mendorong pembeli untuk melakukan keputusan pembelian dalam berbelanja, berbeda halnya jika variabel tersebut saling mendukung.

Produk yang tersaji di swalayan Kota Blitar menjadi prioritas utama pemilik toko untuk menarik para pembeli. Produk sebagai segala sesuatu yang dapat ditawarkan di pasar, untuk memuaskan kebutuhan dan keinginan konsumen, yang terdiri atas barang, jasa, pengalaman, event, orang, tempat, kepemilikan, organisasi, informasi, dan ide (Kotler, 2000:394). Penyediaan berbagai alternatif pilihan produk menjadi salah satu tolok ukur konsumen dalam memandang bahwa terdapat banyak pilihan produk yang dapat dibeli oleh konsumen. Selain itu konsumen juga dapat membandingkan antar produk sejenis dengan produsen yang berbeda sehingga konsumen akn lebih leluasa dalm menentukan pilihannya.

Berikutnya harga harus diperhatikan oleh pemilik swalayan. Harga adalah jumlah uang (ditambah beberapa produk, kalau mungkin) yang dibutuhkan untuk mendapatkan sejumlah kombinasi dari produk dan pelayanan (Swastha,1999:241).Harga murah dan bersaing banyak diminati oleh konsumen. 
Konsumen akan cenderung memilih produk yang tersaji dengan harga yang murah, meski ada pula konsumen lebih menyukai produk degan harga yang lebih mahal dibanding dengan produk yang sejenis. Namun, perlu disadari bahwa meski terdapat perbedaan harga antar produk, konsumen akan tetap cenderung berbelanja pada swalayan yang memberi patokan harga lebih murah dibanding dengan swalayan yang lain. Disini pemilik swalayan harus jeli dalam memberi bandrol harga.

Tempat atau lokasi toko bisa menjadi pemicu dalam melalukan keputusan pembelian. Suasana swalayan yang nyaman, luas, aman, serta parkir yang luas bisa menjadi alternatif konsumen untuk sekedar menengok atau bahkan membeli produk di swalayan tersebut. Tempat (distributor) adalah orang atau perusahaan yang menghubungkan aliran barang drai produsen ke konsumen akhir dan konsumen industrial (Stanton, et al., dalam Tjiptono,1997 :185). Tempat sangat mendukung untuk menarik minat para konsumen. Selain itu, promosi yang menggiurkan dapat menjadi agenda wajib bagi pembeli untuk berbelanja. Dengan adanya promosi seperti special sales dan tadding stamps (Alma, 2005) sering menjadi acuan pembeli dalam berbelanja. Diskon ini biasanya diadakan pada saat hari raya, akhir tahun, peringatan hari-hari tertentu, dan lain-lain. Hadiah biasanya diberikan berupa produk sponsor atau beli 2 dapat 3. Hal-hal tersebut sering dilakukan swalayan, dan hasilnya banyak peminat.

Dengan demikian hendaknya pemilik swalayan dapat mengkombinasikan antara produk, harga, tempat, dan promosi untuk memancing konsumen untuk melakukan pembelian produk di swalayan tersebut. Hal ini diketahu berdasarakan riset yang telah dilakukan, jika produk, harga, tempat, dan promosi saling berdiri sendiri (parsial), maka kemungkinan untuk memberikan pengaruh dalam keputusan pembelian sangat kecil. Berbeda kalau semua faktor (produk, harga, tempat, promosi) saling mendukung, akan memberikan dampak positif dalam penjualan produk dalam artian keputusan konsumen dalam membeli produk yang tersaji di swalayan Kota Blitar akan lebih besar.

\section{KESIMPULAN DAN SARAN}

Pada dasarnya dalam pengambilan keputusan pembelian, konsumen akan melihat beberapa faktor yang menjadi pemicu hal tersebut. Dengan saling mendukungnya faktor produk, harga, tempat dan promosi maka keputusan pembelian akan terjadi. Daya dukung dari masing-masing faktor tersebut dapat mendorong konsumen untuk berfikir dan menganalisa apakah akan membeli produk tersebut atau tidak. Dengan daya dukung faktor yang saling menguatkan, maka dapat terlihat hasilnya bahwa keputusan pembelian akan tercipta lebih besar.

Saran, hendaknya pemilik swalayan peka pada jenis produk yang beredar di pasar. Karena semakin hari variasi produk akan semakin bertambah mengikuti selera konsumen. Dan hendaknya dari itu pemilik swalayan dapat menyajikan produk-produk tersebut serta upayakan untuk menyediakan tempat parkir gratis yang aman, karena dengan hal itu konsumen akan lebih tertarik untuk walau hanya sekedar mampir saja, karena dari sekedar mampir bisa mendorong seseorang untuk berbelanja. 


\section{DAFTAR PUSTAKA}

Alma, Buchari, 2005. Manajemen Pemasaran Dan Pemasaran Jasa. Bandung : Alfabeta.

Bayley, Geoff, and Clive Nancarrow. 1998. Impulse Purchasing: A Qualitative Explanation of The Phenomenon. MCB UP Limited.

Cobb, C. J. and Hoyer W. D. 1986, A Planned Versus Impulse Purchase Behavior, Journal of Retailing, Vol. 62, Winter, pp. 67-81.

Engel, J., and Blackwell, R. 1982. Consumer Behaviour. Dryden Press, Chicago, IL.

Kotler, Philip, Hayes, Thomas, Bloom Paul N. 2002. Marketing Professional Services. Prentice Hall Press. . 2000. Marketing Management. Prentice Hall Inc. dan Gary Amstrong, 1999. Principles of Marketing. Prentice Hall International, Inc. , Swee Hong ang, Siew Meng Leong, Chin Tiong Tan. 1996. Marketing Management : An Asian Perspective. Singapore : Prentice Hall.

Semuel, Hatane. 2006. Dampak Respon Emosi Terhadap Kecenderungan Perilaku Pembelian Impulsif Konsumen On Line Dengan Sumberdaya yang Dikeluarkan dan Orientasi Belanja Sebagai Variabel Mediasi. Jurnal Manajemen dan Kewirausahan, Vol. 8, No. 2, September. Fakultas Ekonomi, Universitas Kristen Petra Surabaya. Hal. 101-115.

Semuel, Hatane. 2007. Pengaruh Stimulus Media Iklan, uang Saku, Usia, dan Gender terhadap Kecenderungan Perilaku Pembelian Impulsif. Jurnal Manajemen Pemasaran, Vol. 2, No. 1, April. Fakultas Ekonomi, Universitas Kristen Petra Surabaya. Hal. 31-42.

Sugiyono, 2007. Statistika Untuk Penelitian (Edisi Revisi Terbaru). Alfabeta : Bandung.

Swastha, Basu, 2001. Manajemen Pemasaran. Edisi Pertama. Cetakan Ketiga. Yogyakarta : BPFE.

Tjiptono,Fandy, 1997. Strategi Pemasaran (Edisi II). Yogyakarta : Andi.

Zeithaml, V.A. dan M.J. Bitner. 1996. Service Marketing. New York : The McGraw-Hill Companies, Inc. 